\title{
COPE - Common Operational Picture Environment
}

\author{
R. KASPRZYK, M. CIEŚLEWICZ, K. KRAJEWSKI, M. PERKA, A. STACHURSKI \\ rkasprzyk@wat.edu.pl
}

Institute of Computer and Information Systems

Faculty of Cybernetics, Military University of Technology

Kaliskiego Str. 2, 00-908 Warsaw

\begin{abstract}
The paper focuses on the attempt to improve the process of reporting and localizing incidents, made within project COPE (Common Operational Picture Environment). The system which is an approach to satisfy a still increasing demand for safety, will have a beneficial influence on the emergency units management. All gathered data about the reported incidents will build an incremental information delivery model that can be useful for creating hazard maps notifying potential users about possible dangers in particular areas.
\end{abstract}

Keywords: Emergency Response Systems, Common Operational Picture, safety-oriented society (SOS).

\section{Introduction}

Every day societies have to deal with various threats. These may either have an environmental background like floods, earthquakes etc. but may result from some criminal activities as well. To minimize any potential loses in both cases, victims always count on quick help from specialized services. With no doubt, their tasks are not only very difficult and demanding, but also require responsibility and a good preparation. Therefore, while undertaking a rescue mission it is always necessary for unit leaders to divide their tasks between their members effectively. Then, in addition to a rapid response and an effective unit coordination, an appropriate resource allocation may prove to be crucial (ASAPx2 - As Soon As Possible Achieve Situational Awareness Predominance). Unfortunately, despite many intensive efforts, which included a variety of scenario practices, this is often troublesome during the action.

It is also worth noting that regardless of the huge technological leap in the last decade, planning and direct performance of the unit actions often seem to be inefficient. Research shows that the currently used Emergency Response Systems developed to report threats are highly ineffective [1]. As military experience shows information superiority and appropriate technical support are the key factors which allow to carry out successful actions much easier, and above all, safer. For this reason it is advisable to develop new approaches that would enhance the effectiveness of these activities owing to the latest technological trends.
The main goal of the paper is to propose a solution showing a possible way of reporting incidents and supporting the process of their handling with a use of ordinary smart phones, called COPE.

\section{The COPE project}

COPE (Common Operational Picture Environment) is the system awarded in several international competitions. This included third place winner award in Windows Phone Challenge category during Imagine Cup 2013 World Finals, organized by Microsoft and silver medal in the "World Exhibition on Inventions, Research and New Technologies" in Brussels. Moreover, COPE system was also appreciated by Polish Minister of Education in 2013. COPE takes advantages of experiences acquired thanks to GUARDIAN system [2] which was developed during Imagine Cup 2012.

GUARDIAN was a new type of Emergency Response System. It had been developed for rapid response to the occurrence of any kinds of threats. Using a mobile technology, including GPS and smart phones, GUARDIAN allows to instantly call for help in just a few seconds. With use of GUARDIAN installed on the phone it is possible to quickly notify the nearby emergency services with just one click about the danger. Therefore, it provides an effective solution, where protecting the health and life of a human is important. All in all GUARDIAN is dedicated to ordinary people and used "to silently call" when you are in danger. 
Whereas COPE is a system addressed to both specialized services, as well as ordinary users. In the first case, well processed and maintained data enables to manage units work involved in any kind of action. It supports commanding process and improves operation performance that can be achieved with information superiority and the use of modern equipment and technology. Its purpose is to support users - both those in the field as well as those working in the command center - so that they can perform their tasks more efficiently. This could be achieved by creating a Common Operational Picture (COP) to improve situational awareness essential for appropriate decisionmaking by an individual, a unit, eventually up to a crisis management center for a dedicated area.

Although most functions of the system are only available for dedicated end users, there is also its limited version for everyone. This gives a broad view of the situation in the neighbourhood on a map, warning about any kind of incidents. At the same time, the user can immediately report the encountered event.

This proves that COPE may seems to be an innovative approach because at the moment there are few alternative systems gathering information about the incidents by sending quick information that is next automatically saved in the database and displayed on another user's map. Existing solutions used by public services focus primarily on available resources, logistics and coordination of their tasks that follow reported incident. However, COPE approach to the problem can be regarded as more comprehensive. First of all, it allows to report the incident immediately. Then it also supports people who want to avoid those incidents by giving a brief view of area on a map. That informs the user about any possible danger. In addition, these users, who are directly involved in the incident can receive for instance some instructions indicating how to behave or what to do in that situation. COPE may certainly cooperate with existing systems, thus the synergy of their use will bring many benefits to each end-user [1], [2].

In order to conduct the project with success, the key was to find such technical approaches that would make the system work quickly and intuitively for most smart phone owners. The anticipated performance of COPE system can be regarded as effective because, with relatively small expenses, it may bring rational benefits resulting from increased safety and situational awareness of the specialized services.

\section{COPE's architecture and used technologies}

COPE is a modular system that works in an n-tier architecture which provides a high level of scalability and extensibility of the system. It consists of three major components, which offer different functions, depending on its dedicated end-users:

- COPE client - running on Windows Phone $7 \& 8$ devices, adjusted to individuals or units directly performing the action. It provides a preview of units on the map and access to operational data supported by augmented reality module [3], [4].

- COPE server - a web-based application, designed for command centers enabling to manage data and units involved in the action with the use of advanced graph algorithms.

- COPE civil - dedicated for civilian mobile devices, providing quick notification services about the incidents and advising in critical situations with AR.

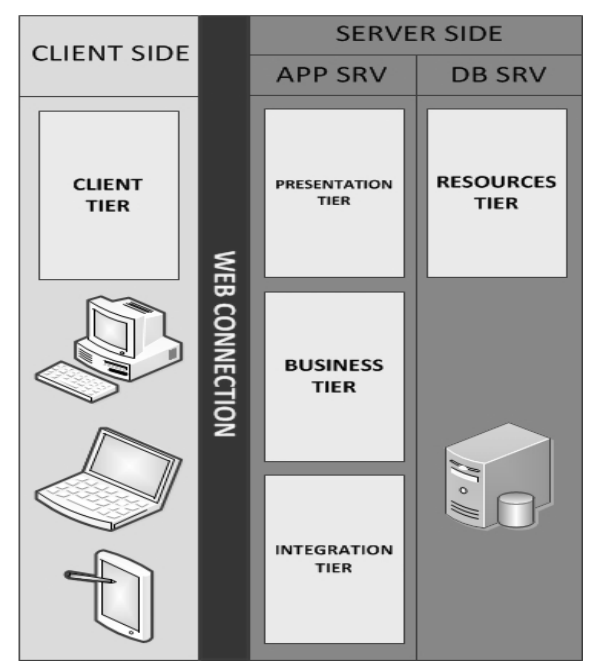

Fig. 1. Architecture overview

- Client tier - to enable the user to interact with software (via mobile application)

- Presentation tier - designed to generate a user-friendly GUI

- Logic tier - responsible for data processing; contains implementation of map algorithms

- Integration tier - tasked to separate data processing from data storage

- Resource tier - to collect and store data.

The whole system configuration, disk space and a database is managed on Windows AZURE platform. Figure 2 presents an overall packetbased structure of COPE system, indicating its layer division. 


\begin{tabular}{|c|c|c|c|c|c|}
\hline & CLIENT & PRESENTATION & BUSINESS & INTEGRATION & RESOURCES \\
\hline APPLICATION & XAML & JavaScript & $\begin{array}{l}\text { Business } \\
\text { components }\end{array}$ & $\begin{array}{c}\text { Entity } \\
\text { Framework } 6\end{array}$ & $\begin{array}{l}\text { Database } \\
\text { schema }\end{array}$ \\
\hline \multirow{2}{*}{$\begin{array}{l}\text { VIRTUAL } \\
\text { PLATFORM }\end{array}$} & \multirow{2}{*}{$\begin{array}{l}\text { Windows } \\
\text { Presentation } \\
\text { Fundation }\end{array}$} & \multirow{2}{*}{$\begin{array}{l}\text { Model View } \\
\text { ViewModel }\end{array}$} & \multirow{2}{*}{$\begin{array}{l}\text { NET Platform + } \\
\text { C\# } 4.5\end{array}$} & ADO.NET & \multirow{2}{*}{ SQL/DDL } \\
\hline & & & & WCF & \\
\hline $\begin{array}{c}\text { UPPER } \\
\text { PLATFORM }\end{array}$ & $\begin{array}{l}\text { Web broswer } \\
\text { (e. g Internet } \\
\text { Explorer 11) }\end{array}$ & \multicolumn{3}{|c|}{ IIS 8} & \multirow{3}{*}{ Microsoft Azure } \\
\hline $\begin{array}{l}\text { LOWER } \\
\text { PLATFORM }\end{array}$ & Any OS & \multicolumn{3}{|c|}{ Microsoft Windows Server 2012 R2 } & \\
\hline $\begin{array}{l}\text { HARDWARE } \\
\text { PLATFORM }\end{array}$ & Any PC & \multicolumn{3}{|c|}{ Intel Xeon Phi Server } & \\
\hline
\end{tabular}

Fig. 2. Packet-based structure of layers

\section{Threats' maps}

The architecture described in the previous chapter proves that the system enables rapid data collection including incidents localization. Equally, a time-saving one-button event notification may bring huge benefits in decision making and from operational point of view the probability of success may increase.

Collected data is then permanently stored. So that, it is worth mentioning that users are a key element of the system. The more active users are signed up, the more incidents can be reported.
This way COPE boosts a great chance to gather more data to be analyzed. Using gathered data, the system will be able to create Threats' maps, which will show the most dangerous areas, sorted by the type of a threat. Of course, the amount of data will grow over time. A variety of its dedicated analyses may indicate any crucial changes for instance in the process of planning or human resource management.

In the long run this knowledge will enable decision makers to assess the efficiency and accuracy of procedures and services' performance.

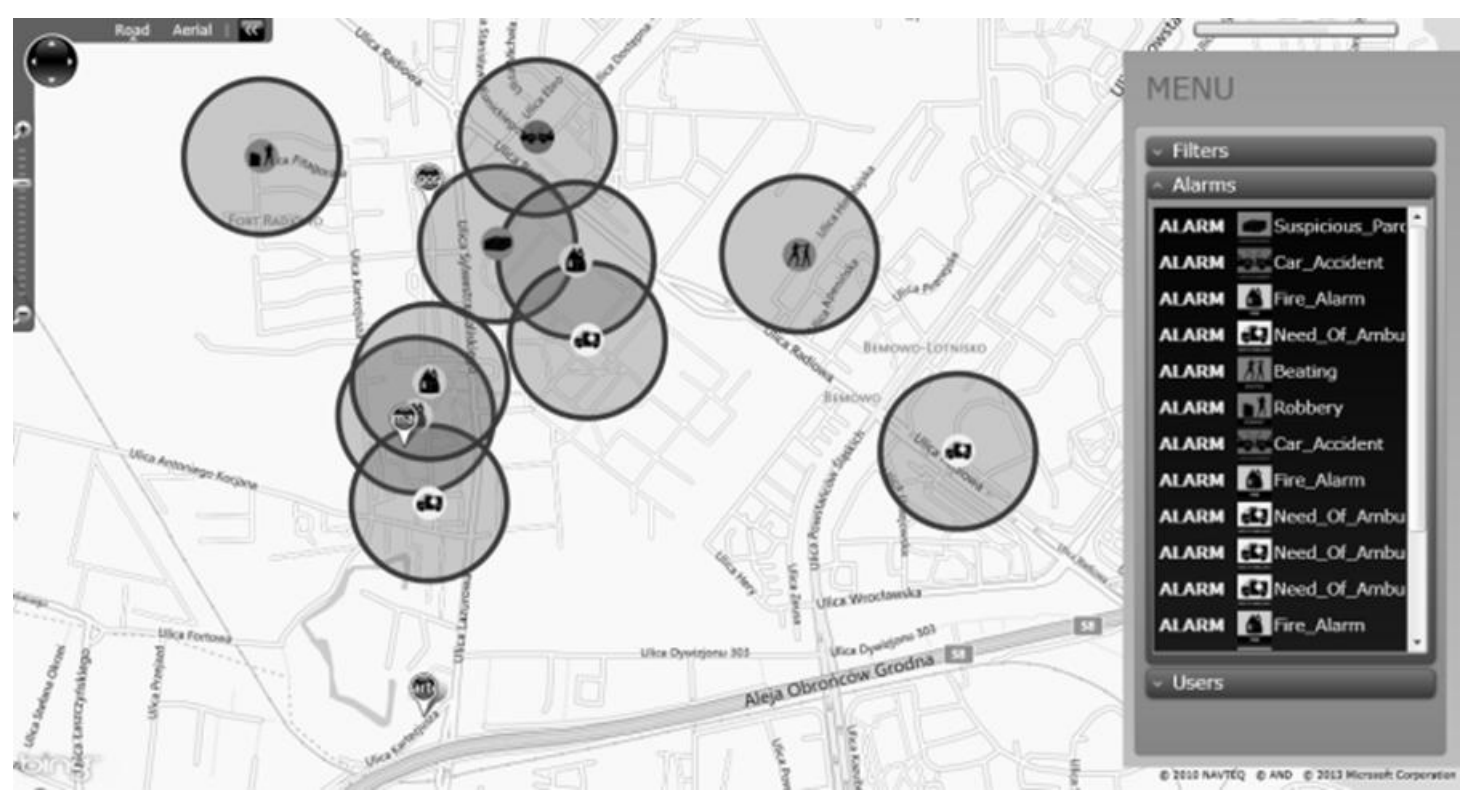

Fig. 3. Map of incidents 


\section{Graphical user interface}

Both mobile and web applications have an intuitive and simple interface. Most functions implemented in COPE system do not require any advanced technical skills. Navigation bars in mobile devices allow comfortably to switch between the application modules.

When the user decides to report danger, a list of pre-defined incidents is shown. These, together with all active users are displayed on an interactive map background as clickable pushpins.

a

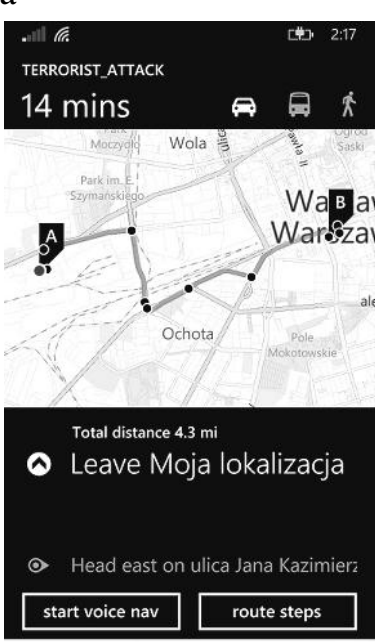

b

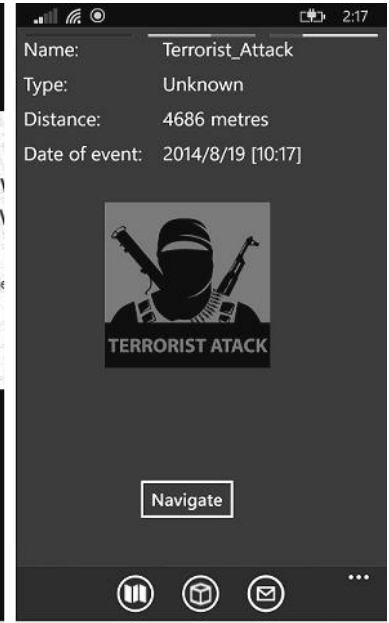

c

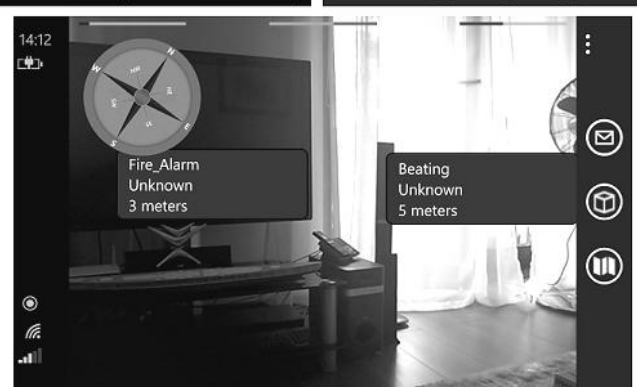

Fig. 4. GUI overview : a - route planner; $b$ - event notification; c - augmented reality module

As for the web application, it gives a broad view of the situation on the map component. It includes a set of panels for users management that enable to establish connection and exchange data with any of them.

\section{COPE functionality "in a pill"}

Any kind of action that is undertaken by specialized services has to follow some fixed procedures. COPE system offers functions that may facilitate and accelerate that process.

One function that mobile applications offer allows one-button event notification. This significantly reduces time to report the incident. After its initialization an application gathers: personal data of the user that is preconfigured, for example: blood type, medical history and many more.

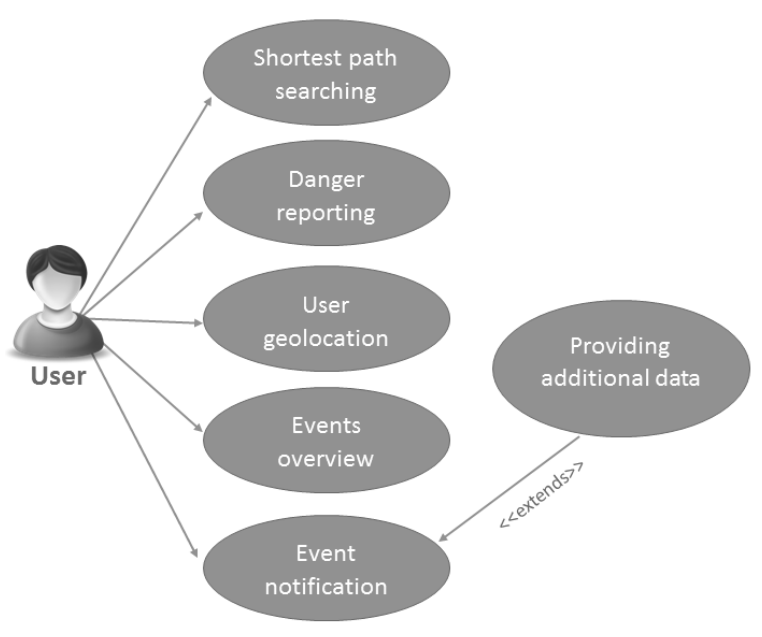

Fig. 5. Use Case diagram

Then it gets data from the phone built-in GPS and a type of the alarm (selected from an intuitive list of images) which are then immediately sent to the database. In the next step, mobile application user may send additional data linked to the particular alert.

System allows to view all users and reported incidents on a Bing map component as well as with the use of Augmented Reality feature. In AR module, by focusing a phone camera on a particular object, its location and info are displayed [5]. Details of each map object are taken from SQL AZURE database. This is continuously updated and gives the most current information which improves synchronization of users' performance. It includes:

- GPS info

- text messages

- images

- notifications.

There were also external libraries from Hawaii Project used that enable speech recognition, which accelerates the process of messaging. [6] Furthermore, the map component offers built-in algorithms to indicate optimal routes between given points on a map.

A web application that plays the role of a command center provides the view of the whole situation on a map including information about events, marked areas and users within teams - their skills, position and status. These factors have continuous influence on situational awareness. 


\section{Development opportunities}

At present, the COPE project is in the final stage of prototype development, however, today's capabilities of smart phones and web applications prove that it can be widely extended.

As far as the augmented reality is concerned, objects displayed within this environment will have to be re-designed to match current visual standards. Equally, AR objects categorization would both make them clearer and simplify their searching and filtering. Following the newest technology achievements, smart phone modules could be extended to work with augmented reality glasses and the user interface could be extended to be controlled by voice.

It is also planned to enhance routing functions that would indicate the path between given points, that would avoid places where any kind of incidents were reported.

As the alerts reported with COPE may be followed by health hazard, it would be beneficial for the user to enable to include some of their medical information. In circumstances, where several people are involved, this would be read with an adjusted NFC module or from a database to accelerate or improve first aid.

\section{Summary}

With no doubt it is not possible to eliminate dangers that we face, however, system that was described in the article is an attempt to make the process of reporting incidents and their localizing more efficient.

One of the main advantages of the mobile application is that an incident reporting function works immediately. While reporting the user does not have to give any personal info which is given during registration process or details about location which are obtained from GPS.

It is also worth noting that the system, which provides a layered architecture, is flexible and its functionalities can be easily updated and customized for the needs of the particular end-user.

All in all, we are certainly sure that COPE system may not only increase the security of the specialized service users but also security of any of us. Since the launch of COPE system it will be gradually creating an incident map that may be used for further incident analysis and wise investment of money for security.
Data gathered from a mobile device may become a sufficient tool that will help us to prevent or cope with dangers we can face every day.

\section{Bibliography}

[1] http://www.straz.gov.pl/data/binaries/pdf/ spr_opis.pdf - „Założenia do organizacji i funkcjonowania systemu powiadamiania ratunkowego na obszarze województwa", Warszawa, 2008.

[2] Kasprzyk R., Zabielski M., Kowalski P., Oksiuta G., Rzempołuch K., "GUARDIAN - Emergency Response System with Incremental Information Delivery Model", Biuletyn Instytutu Systemów Informatycznych, Vol. 11, 1-6, 2013.

[3] http://www.wasko.pl/lista-produktow/ 89-swd-system-wspomagania-dowodzenia.

[4] http://kwartalnik.csp.edu.pl/kp/ archiwum-1/2014/nr-2014/2161,SYSTEMWSPOMAGANIA-DOWODZENIA-WPOLICJI.html.

[5] Pardel P., "Przegląd ważniejszych zagadnień rozszerzonej rzeczywistości", STUDIA INFORMATICA, Vol. 30, No. 1(82), 35-63, 2009.

[6] Azuma R.T., "A Survey of Augmented Reality", In Presence: Teleoperators and Virtual Environments 6, 4 (August 1997), 355-385, 1997.

[7] GART. [Online] http://gart.codeplex.com/.

[8] Hawaii Project. [Online] http://research.microsoft.com/enus/projects/hawaii/. 


\section{COPE - Common Operational Picture Environment}

\section{R. KASPRZYK, M. CIEŚLEWICZ, K. KRAJEWSKI, M. PERKA, A. STACHURSKI}

Artykuł ma na celu przedstawienie możliwości wykorzystania systemu COPE w procesie zgłaszania incydentów oraz optymalizacji działania służb ratunkowych. COPE jest odpowiedzią na zwiększającą się potrzebę poprawy poziomu bezpieczeństwa publicznego. Koncepcja systemu polega na wytworzeniu wspólnego obrazu operacyjnego i wykorzystaniu go na potrzeby zwiększenia świadomości sytuacyjnej w procesie podejmowania decyzji. Dodatkowo informacje o zaistniałych incydentach gromadzone są w bazie wiedzy celem budowy map zagrożeń oraz oceny efektywności służb i istniejących procedur.

Słowa kluczowe: Systemy Reagowania Kryzysowego, Wspólny Obraz Operacyjny, społeczeństwo zorientowane na bezpieczeństwo. 